JOPPAS: Journal of Public Policy and Administration Silampari

Volume 1, Nomor 1, Desember 2019

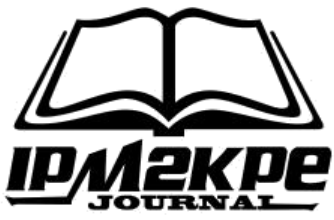

\title{
KINERJA SATPOL PP DALAM UPAYA MEWUJUDKAN KETERTIBAN UMUM DI KOTA SUKABUMI
}

\author{
Yulia, Ike Rachmawati, Andi Mulyadi \\ Program Studi Ilmu Administrasi Publik, Universitas Muhammadiyah Sukabumi \\ yuliacitra947@gmail.com
}

\begin{abstract}
ABSTRAK
Tujuan penelitian untuk mengetahui bagaimana Kinerja Satpol PP dalam upaya mewujudkan ketertiban umum di Kota Sukabumi. Penelitian ini menggunakan grand theory Bernardin dan Russel dan merupakan jenis penelitian deskriptif dengan pendekatan kualitatif, dengan menggunakan teknik purposif sampling.Dalam penyusunan data primer, peneliti memperoleh data dari lapangan, yaitu bersumber dari hasil wawancara dan observasi dengan responden. Berdasarkan hasil penelitian, kinerja Satpol PP dalam upaya mewujudkan ketertiban umum di Kota Sukabumi masih sangat jauh dari keberhasilan karena tujuan dari Satpol PP dalam upaya mewujudkan ketertiban umum di Kota Sukabumi dalam menangani pelajar yang membolos belum ada kesempurnaan atau mendekati tujuan yang diharapkan seperti apa yang diinginkan oleh pembuat kebijakan, dan Sumber daya di Dinas Satpol PP Kota Sukabumi masih belum cukup, sedangkan jumlah permasalahan yang ada dalam ketertiban umum yang ada di Kota Sukabumi begitu banyak dan luas. Serta Kerja sama belum berjalan dengan baik karena masyarakat hanya mengandalkan tindakan Satpol PP.
\end{abstract}

Kata Kunci : Kinerja, Ketertiban Umum.

\section{ABSTRACT}

The purpose of this research is to find out how the performance of Satpol PP in an effort to realize public order in the City of Sukabumi. This study uses Bernardin and Russel's grand theory and is a type of descriptive research with a qualitative approach, using purposive sampling techniques. In preparing primary data, researchers obtain data from the field, which is sourced from interviews and observations with respondents. Based on research results, the performance of Satpol PP in an effort to realize public order in Sukabumi City is still very far from success because the goal of Satpol PP in an effort to realize public order in the City of Sukabumi in dealing with students who play truant is not yet perfect or approaching the expected goals as what is desired by policy makers, and the resources in the Sukabumi City Satpol PP Office are still not enough, while the number of problems that exist in public order in the City of Sukabumi is so numerous and extensive. And Cooperation has not gone well because the community only relies on the actions of Satpol PP.

Keywords: Performance, Public Order. 


\section{PENDAHULUAN}

Perilaku membolos sebenarnya bukan merupakan hal yang baru lagi bagi sebagian besar siswa. Tindakan membolos merupakan salah satu tindakan siswa untuk melampiaskan kejenuhan mereka akan pendidikan. Akhirnya memang akan menjadi fenomena yang jelas-jelas mencoreng lembaga pendidikan dan siswa itu sendiri. Semua itu disebabkan oleh faktor-faktor internal dan eksternal dari anak itu sendiri. Faktor eksternal yang kadang kala menjadikan alasan membolos adalah mata pelajaran yang yang tidak diminati dan tidak suka dengan guru mata pelajaran. Sedangkan faktor internal yakni siswa menganggap masa remaja adalah masa pencarian jati diri yang penuh dengan jiwa yang mementingkan kebebasan dalam berfikir dan berkreatifitas, karena masa remaja adalah masa yang penuh gelora dan semangat kreatifitas. Mereka yang tidak dapat beradaptasi dengan situasi seperti itu mereka akan mencari penyelesaian lain dengan cara membolos. Walaupun begitu membolos sebenarnya bukan jawaban yang utama untuk melampiaskan keadaan yang seperti itu, dan kegiatan membolos juga hal yang dapat melatar belakangi timbul masalah masalah lain.

Terbukti, siswa yang suka membolos seringkali terlibat dengan hal-hal yang cenderung merugikan diri sendiri dan orang lain seperti merokok, tawuran, dan pergaulan bebas, yang dapat meresahkan masyarakat, Betapa seriusnya perilaku membolos ini perlu mendapat perhatian penuh dari berbagai pihak. Bukan saja pihak sekolah tetapi juga orang tua, teman dan pemerintah. Perilaku membolos sangat merugikan dan bahkan itu bisa saja sumber masalah baru. hal ini terus-terusan dibiarkan bukan saja siswa itu sendiri tetapi juga sekolah dan guru yang menjadi orang tua di sekolah yang menangungnya. Banyak kasus-kasus yang diakibatkan oleh membolos seperti yang telah diuraikan di atas dampak buruk bagi sekolah, siswa yang suka membolos sering mencontoh gaya penampilan teman sebaya dari sekolah lain yang tidak sesuai dengan aturan yang ada di sekolahnya sehingga menghambat kedisiplinan yang diterapkan dan siswa yang membolos dapat menghambat pencapaian tujuan pembelajaran di kelas. Oleh karena itu diperlukan bantuan pihak satpol PP untuk melakukan penertiban untuk meningkatkan kenyamanan masyarakat.

Karena ketertiban, keamanan dan kenyamanan merupakan suatu keadaan yang tidak bisa dipisahkan dari kehidupan bermasyarakat. Dalam rangka mewujudkan Kota Sukabumi sebagai kota yang dapat memberikan kenyamanan, ketenteraman, dan ketertiban bagi seluruh warga masyarakat, maka dipandang perlu adanya Pengaturan ketertiban umum, sebagaimana dimaksud dalam Peraturan Daerah Kota Sukabumi Nomor 2 Tahun 2004 Tentang Ketertiban Umum. Menyebutkan bahwa Setiap orang berhak untuk memperoleh kenyamanan atas bangunan atau rumah yang dimilikinya, atau yang dikuasainya secara sah, Serta menikmati ketenteraman, dan ketertiban lingkungan.

Satpol PP memiliki peran yang cukup penting dalam menjaga ketertiban dan ketentraman Kota Sukabumi karena berperan sebagai koordinator operasional lapangan, ada 140 personil Satpol PP di Kota Sukabumi dan ada Beberapa tugas yang secara rutin 
dilakukan oleh Satpol PP Kota sukabumi dalam menjaga ketertiban umum dan ketentraman masyarakat adalah seperti menjaga keamanan di tempat keramaian, ikut menjaga pengaturan lalu lintas, dan peningkatan pelayanan masyarakat. Dalam melaksanakan perannya, Satpol PP melakukan 3 langkah dalam menjaga ketertiban dan ketentraman, yaitu operasi dalam bentuk persuasif dimana Satpol PP melakukan pendekatan kepada masyarakat dalam bentuk diskusi dan sosialisasi, langkah berikutnya yang dilakukan Satpol PP adalah dalam bentuk operasi preventif di mana Satpol PP memberikan surat peringatan kepada pihak-pihak yang melanggar ketentuan dan langkah terakhir adalah operasi represif dalam bentuk eksekusi yang dilakukan Satpol PP terhadap pihak yang melanggar ketentuan peraturan perundang- undangan maupun peraturan daerah yang berlaku.

Selain itu, diamanatkan pula bahwa dalam rangka pelaksanaan kewajiban dibidang pemeliharaan ketentraman dan ketertiban masyarakat serta penegakan peraturan daerah dan peraturan pelaksanaannya, dibentuk Satuan Polisi Pamong Praja (Satpol PP). Yang merupakan perangkat pemerintah daerah dalam memelihara ketentraman dan ketertiban umum serta menegakan peraturan daerah Satuan Polisi Pamong Praja, disebutkan juga dalam Pasal 3 Peraturan Pemerintah (PP) No. 6 Tahun 2010 Tentang Satuan Polisi Pamong Praja menyelenggarakan fungsi yaitu: 1) penyusunan program dan pelaksanaan ketentraman dan ketertiban umum, penegakan Peraturan Daerah dan Keputusan Kepala Daerah, 2) pelaksanaan kebijakan pemeliharaan dan penyelenggaraan ketentraman dan ketertiban umum di Daerah, 3) pelaksanaan kebijakan penegakan Peraturan Daerah dan Keputusan Kepala Daerah, 4) pelaksanaan koordinasi pemeliharaan dan penyelenggaraan ketentraman dan ketertiban umum serta penegakan Peraturan Daerah, Keputusan Kepala Daerah dengan aparat Kepolisian Negara, Penyidik Pegawai Negeri Sipil (PPNS) dan atau aparatur lainnya, 4) pengawasan terhadap masyarakat agar mematuhi dan mentaati Peraturan Daerah dan Keputusan Kepala Daerah.

Berdasarkan Pasal 3 Peraturan Pemerintah No. 6 Tahun 2010 Tentang Satuan Polisi Pamong Praja, Satuan Polisi Pamong Praja juga berwenang: 1) menertibkan dan menindak warga masyarakat atau badan hukum yang mengganggu ketentraman dan ketertiban umum, 2) melakukan pemeriksaan terhadap warga mayarakat atau badan hukum yang melakukan pelanggaran atas peraturan daerah dan keputusan kepala daerah, 3) melakukan tindakan represif non yustisial terhadap warga masyarakat atau badan hukum yang melakukan pelanggaran atas peraturan daerah dan keputusan kepala daerah.

Berdasarkan hasil observasi awal peneliti berdasarkan perda Nomor 2 tahun 2004 tentang ketertiban umum di Kota Sukabumi Peneliti memandang keberadaan satpol pp sebagai penegak perda ketertiban umum masih dirasa belum optimal ini dapat dilihat dari beberapa fenomena antara lain: 1) pelaksanaan kegiatan untuk mengurangi para pelajar yang membolos yang dilakukan belum optimal, contohnya ketika dilakukan penertiban para pelajar yang menganggu ketertiban umum masih tetap kembali 
melakukan aksinya. Di karnakan sebagian dari pelanggar ketertiban hanya diberikan sangsi Administratif yaitu sangsi teguran lisan dan pembinaan saja. Tidak ada sangsi kuat untuk para pelanggar ketertiban umum, 2) jumlah sumberdaya belum optimal, ini terlihat dari data yang diperoleh peneliti. terhitung hingga Desember 2018, bahwa sumber daya yang ada hanya 140 personil yang terbagi beberapa bagian, seperti ada yang di staff, dirumah dinas, kantor pemda, kantor dewan, dan ada yang dilapangan, Padahal angka idealnya berdasarkan peraturan menteri dalam negeri Republik Indonesia Nomor 60 tahun 2012 tentang pedoman penetapan jumlah polisi pamong praja adalah 250 personil, 3) tidak ada kerja sama, Satpol PP merasa kewalahan saat masyarakat mengadukan segala keluhan kepada pihaknya. Padahal yang bertanggung jawab, untuk menjamin kenyamanan serta ketertiban umum, bukan Satpol PP saja, pihak kecamatan dan kelurahan juga memiliki peran dan tanggung jawab atas berlangsungnya ketertiban di masyarakat.

\section{METODE PENELITIAN}

Jenis penelitian yang digunakan dalam penelitian ini adalah studi kasus. Alasan digunakannya pendekatan penelitian ini adalah karena peneliti melihat sifat dari masalah yang dapat dikembang secara alamiah sesuai dengan situasi dan kondisi lapangan serta desain ini berusaha menggambarkan kehidupan dan tindakan tindakan manusia secara khusus pada kasus tertentu dan lokasi tertentu. Peneliti juga berkeyakinan bahwa dengan pendekatan alamiah, penelitian ini menggunakan informasi yang lebih banyak. Rancangan penelitian ini dibuat sebagaimana umumnya rancangan penelitian yang menggambarkan pendekatan kualitatif, umumnya bersifat lebih banyak memperhatikan teori subtantif dari data empiris yang didapat dilapangan.

\section{HASIL PENELITIAN}

Quality (kualitas) Merupakan tingkat sejauh mana proses atau hasil pelaksanaan kegiatan mendekati kesempurnaan atau mendekati tujuan yang diharapkan.Terkait mengenai kualitas ini bisa dilihat dari bagaimana para pelaksana dan juga para masyarakat dan pelajar yang membolos mengetahui dan paham mengenai tujuan dari kebijakan ini. Untuk melihat bagaimana para pelaksana kebijakan dan juga para masyarakat dan pelajar yang membolos maka peneliti mencoba mencari tahu kepada beberapa informan yang terlibat di dalam penelitian ini. Pertanyaan pertama yang peneliti ajukan kepada informan 1, 2, dan 3 yaitu : Sejauh mana kegiatan yang dilakukan dalam menangani para pelajar yang memblos?

Dari hasil wawancara dengan informan 1, mengemukakan bahwa pihak SATPOL PP melakukan penanganan berupa pembinaan dan penyuluhan, dengan cara memberikan pembinaan ringan dan pembinaan fisik. Terhadap para pelajar yang membolos di jam pelajaran sekolah, tetapi para pelajar tersebut tidak ada efek jera, mereka kembali membolos di jam pelajaran sekolah, ini dikarenakan tidak ada sangsi hukum yang kuat untuk menindak lanjuti para pelajar tersebut, yang akan membuat 
para pelajar merasa takut untuk kembali melakukan kegaduhan yang meresahkan masyarakat.
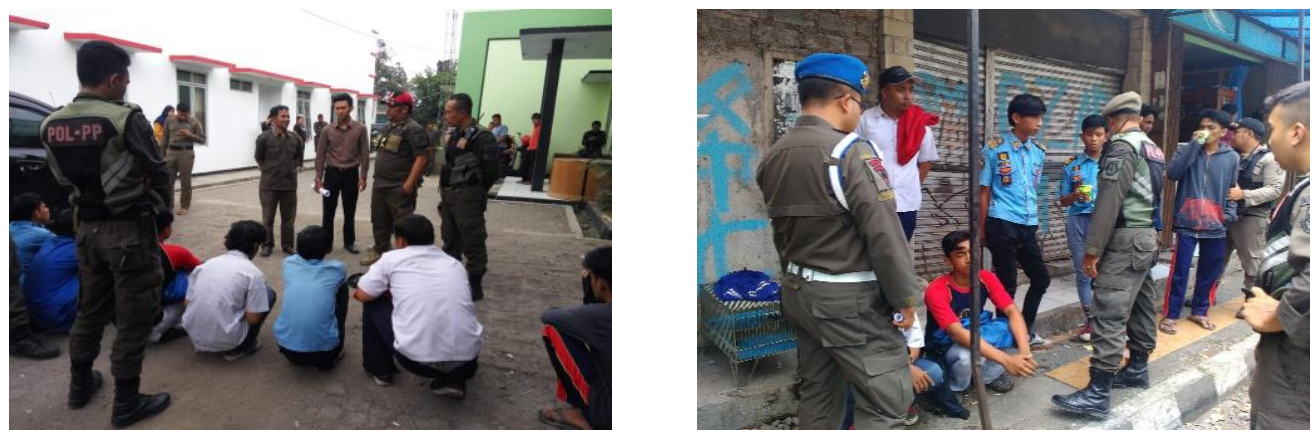

Sumber Dinas Satpol PP Kota Sukabumi

Gambar 1 Dokumentasi Pengamanan Pelajar yang Membolos

Berikut adalah dokumentasi saat Dinas Satpol PP melakukan penertiban dan memberikan arahan terhadap para pelajar yang membolos saat jam pelajaran sekolah, para pelajar tersebut dikumpulkan di Kantor Dinas SATPOL PP untuk diberikan wejangan dan pembinaan fisik, penertiban di lakukan di JL RE Martadinata, Lapang merdeka. Dan dilakukan setiap satu minggu sekali ataupun ketika ada laporan dari masyarakat terkait pelajar yang sedang nongkrong atau membuat onar di jam pelajaran sekolah.

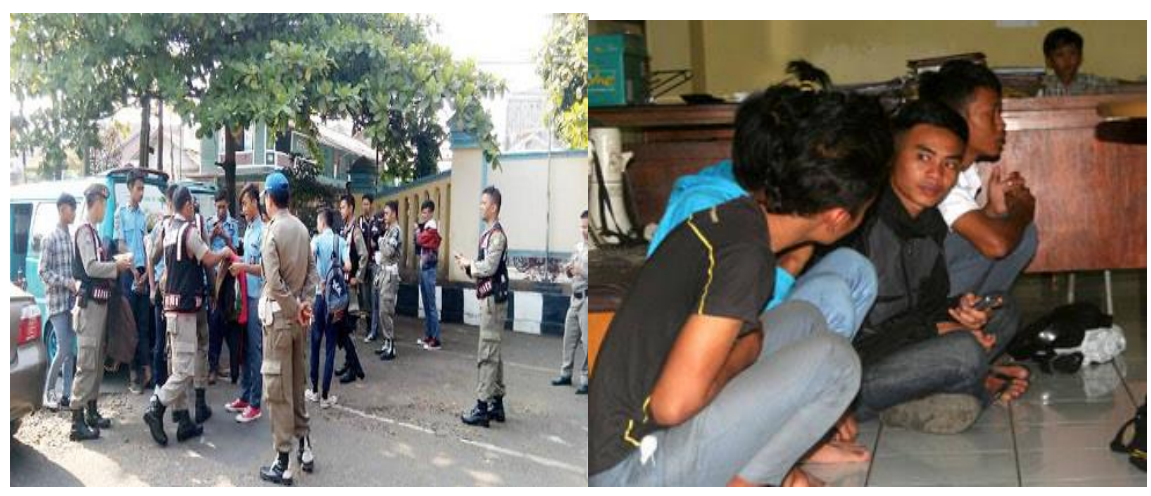

Sumber Dinas Satpol PP Kota Sukabumi

Gambar 2 Dokumentasi Pengamanan Pelajar yang Tawuran

Berdasarkan dokumentasi diatas dapat dijelaskan bahwa anggota SATPOL PP mengamankan para pelajar yang tawuran di sekitar lapang merdeka, para pelajar tersebut diamankan untuk diberikan pembinaan agar mereka tidak kembali melakukan aksinya yang membuat resah masyarakat setempat. Penertiban dilakukan setiap ada laporan dari pihak-pihak terkait mengenai pelajar yang sedang tawuran. Pertanyaan yang sama selanjutnya peneliti ajukan kepada informan 2. Dari hasil wawancara dengan informan 2, mengemukakan bahwa, kenakalan remaja dan pelajar yang membolos di 
jam pelajaran sekolah terjadi akibat tidak adanya motivasi belajar pada siswa tersebut, Ini Diakibatkan karena pengaruh lingkungan, perkembangan teknologi yang tidak diimbangi dengan penggunaan yang bijak dan sesuai dengan aturan. informan 2 telah melakukan penanganan dengan cara memberikan arahan dan motivasi-motivasi belajar kepada para siswa tetapi sampai saat ini belum ada hasil dari upaya pihak sekolah tersebut.

Dari hasil observasi wawancara dengan informan, selanjutnya peneliti menggambungkan dengan teori dari jurnal Ibrahim (2015) dari Universitas Muhammadiyah Surakarta yang berjudul hubungan antara motivasi belajar dengan perilaku membolos pada siswa kelas viii smp batik Surakarta, menerangkan bahwa menurut clayton alderfer motivasi belajar adalah kecenderungan siswa dalam melakukan kegiatan belajar yang didorong oleh hasrat untuk mencapai prestasi atau hasil belajar sebaik mungkin. motivasi dipandang sebagai dorongan mental yang menggerakkan dan mengarahkan perilaku manusia, termasuk perilaku belajar. dalam motivasi terkandung adanya keinginan yang mengaktifkan, menggerakkan, menyalurkan dan mengarahkan sikap serta perilaku pada individu belajar. Teori tersebut sangatlah penting untuk di ketahui para pelajar sehingga mereka tidak membolos di waktu belajar.

Pertanyaan yang sama selanjutnya peneliti ajukan kepada informan 3, dari hasil wawancara dengan informan 3 , mengemukakan bahwa informan tersebut melakukan pemantauan, di tempat dimana para pelajar yang membolos pada jam pelajaran sekolah, saat para pelajar nongkrong seperti di Jl.Syamsudin S.H, Gg Adirja Gg Ajid, kemudian informan tersebut memberikan arahan dan himbauan kepada para pelajar yang membolos agar tidak melakukan hal itu kembali.

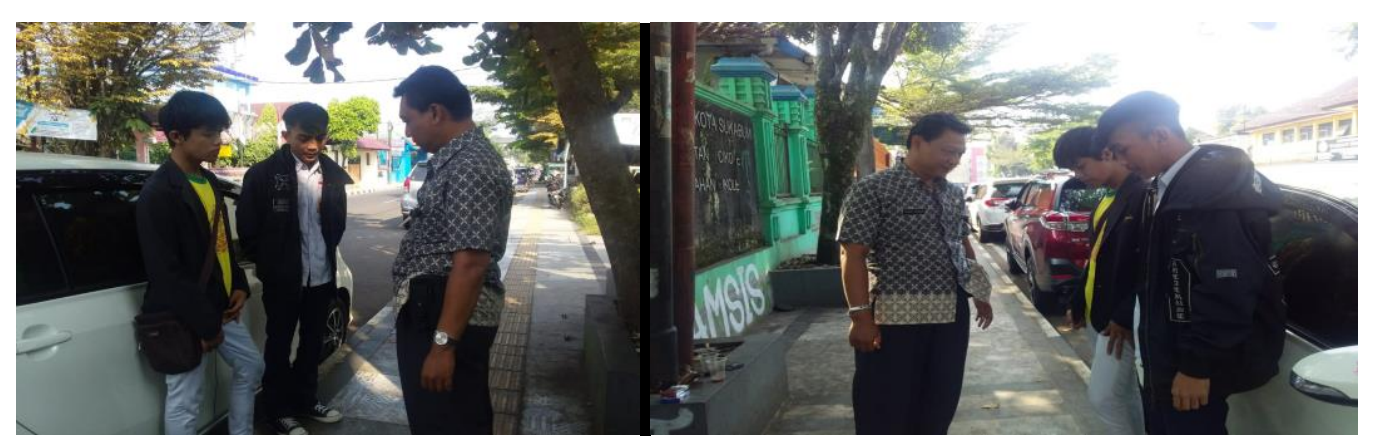

Sumber kelurahan cikole kota sukabumi

Gambar 3 Dokumentasi Pengamanan Pelajar yang Membolos

Berikut adalah dokumentasi saat pihak kelurahan melakukan penertiban dan memberikan arahan dan pembinaan terhadap para pelajar yang membolos saat jam pelajaran sekolah dokumentasi diambil di J1 R. syamsudin S.H. Dari gambar diatas menunjukan bahwa belum tercapainya tujuan dari mewujudkan ketertiban umum di Kota Sukabumi dalam hal ini kualitas SATPOL PP dalam upaya penertiban Masih 
kurang karna tidak adanya ketegasan, Seperti dalam jurnal Gunawan (2012) yang berjudul Penyelenggaraan Ketentraman Dan Ketertiban Umum Oleh Satpol Pp Dan Penyidik Pegawai Negeri Sipil Di Provinsi Aceh mengemukakan bahwa.

Untuk informan 4 dan informan 5 pertanyaan ini tidak termasuk pertanyaan yang diajukan peneliti karena, informan 4 dan informan 5 berada di luar organisasi dinas satpol pp Kota Sukabumi jadi mereka tidak akan mengetahui. Berdasarkan hasil observasi dan wawancara tersebut dapat di interpretasikan bahwa dari beberapa jawaban informan mengenai kinerja SATPOL PP dalam upaya mewujudkan ketertiban umum di Kota Sukabumi yang berfokus pada pelajar yang membolos masih belum optimal. Sebenarnya sasarannya tidak hanya ditujukan kepada para pelajar yang mebolos saja, namun masih banyak permasalahan tentang ketertiban umum yang harus ditangani oleh SATPOL PP Kota Sukabumi, tujuannya sebenarnya agar tidak ada lagi para pelajar yang membolos dan yang melakukan hal-hal yang membuat resah masyarakat dengan memberikan arahan pembinaan dan teguran. Diharapkan mampu membuka wawasan dan pengetahuan kepada para pelajar supaya tidak lagi membolos dan meresahkan masyarakat, tetapi para pelajar yang suka membolos yang sudah diberikan arahan dan pembinaan mereka tetap kembali membolos di jam pelajaran sekolah, hal ini sulit dihilangkan karena para pelajar tidak merasa jera karna mereka tidak mendapat sangsi yang membuat mereka ada efek jera yang membuka pola pikir mereka untuk menjadi pelajar yang baik.

Dari hasil wawancara tersebut peneliti memandang bahwa pelaksanaan kegiatan penertiban di kota Sukabumi oleh dinas satpol PP belum berjalan dengan baik. Apabila hasil pelaksanaan kegiatan berjalan dengan baik atau mendekati tujuan yang diharapkan seperti apa yang diinginkan oleh pembuat kebijakan, maka proses kinerja satpol PP juga menjadi efektif, dapat pula dinyatakan bahwa hasil dari pelaksanaan dalam upaya penertiban para pelajar yang membolos yaitu oleh SATPOL PP belum mencapai keberhasilan yang cukup baik, hal ini akan mempengaruhi dari hasil kerja SATPOL PP, karna para penegak hukum dikatakan berhasil apabila mereka dapat menjalankan plaksanaan kebijakan dengan baik seperti yang dikemukakan oleh Bernardin dan Russel dalam Sutrisno (2010) yang mengemukakan bahwa ada enam kinerja primer yang dapat digunakan untuk mengukur kinerja salah satunya yaitu Quality (kualitas), (Merupakan tingkat sejauh mana proses atau hasil pelaksanaan kegiatan mendekati kesempurnaan atau mendekati tujuan yang diharapkan).

Cost Effectiveness (efektivitas biaya) merupakan tingkat sejauh mana penggunaan sumber daya organisasi (manusia, keuangan, teknologi, dan material). Dalam Pelaksanaan program untuk mengukur kinerja diperlukan waktu yang cukup dan di dukung oleh sumber daya yang memadai. Sumber daya menunjuk setiap kinerja dalam kebijakan yang harus didukung oleh sumber daya yang memadai, baik sumberdaya manusia maupun sumberdaya finansial. Maka dari itu peneliti ingin mengetahui bagaimana sumber daya yang ada di dinas satuan polisi pamong praja, dalam pelaksanaan penertiban yang dilakukan oleh dinas satuan polisi pamong praja 
dalam upaya mewujudkan ketertiban umum di Kota Sukabumi yang berfokus kepada pelajar yang membolos.

Berikut peneliti mengajukan Pertanyaan kepada informan 1, 2 dan 3 yaitu : Bagaimana kondisi sumber daya yang ada apakah sudah cukup atau belum ?. Dari Hasil wawancara dengan informan 1, mengemukakan bahwa di wilayah Kota Sukabumi yang cukup luas, dan ada banyak permasalahan mengenai ketertiban umum yang harus ditangani oleh pihak SATPOL PP, sedangkan jumlah tenaga keja yang ada di dinas SATPOL PP Kota Sukabumi masih belum memadai, jumlah keseluruhan hanya ada 140 personil yang dibagi ke beberapa bagian staf, sedangkan jumlah idealnya dalam anggota SATPOL PP yang dibutuhkan adalah 250 personil angka ini sangat jauh dari jumlah anggota yang ada saat ini.

Lalu peneliti pun bertanya dengan pertanyaan yang sama kepada informan 2 Dari hasil wawancra dengan informan 2 mengemukakan bahwa sumber daya yang ada di Sekolah yaitu para guru dan staf masih belum di rasa Cukup walaupun para guru di sekolah tersebut dengan lulusan Setara Satu dan S2, tetapi jumlah sumber daya manusianya masih belum memadai. Kemudian peneliti bertanya kepada informan 3 dengan pertanyaan yang sama. Dari hasil wawancara dengan informan 3, mengemukakan bahwa Jumlah Sumber daya yang ada memang sangatlah kurang, tidak sesuai dengan luas wilayah Kota Sukabumi, sedangkan pelanggar ketertiban umum yang harus mereka tertibkan sangat banyak. Untuk informan 4 dan informan 5 pertanyaan ini tidak termasuk pertanyaan yang diajukan peneliti karena, informan 4 dan informan 5 berada di luar organisasi dinas satpol pp Kota Sukabumi jadi mereka tidak akan mengetahui.

Dari jawaban beberapa informan tersebut, peneliti menginterpretasikan bahwa sumber daya manusia yang ada di dinas SATPOL PP Kota Sukabumi memang kurang. karena seharusnya jumlah personil Satpol PP lebih banyak lagi. Tetapi kenyataannya jumlahnya tidak memadai dan terlihat dari jawaban informan 3, bahwa sumber daya yang ada di satpol pp memang kurang karena jumlah personilnya hanya 140 orang yang dibagi ke beberapa bagian. Sumber daya aparatur yang lebih utama adalah untuk menjalankan tugas-tugas dan kewajiban mereka, agar apa yang diharapkan dalam pencapaian yang menghasilkan kerja tersebut dapat dijalankan dengan baik namun dengan kurangnya sumber daya manusia akan menjadi penghambat juga karena tidak akan terlaksana secara maksimal.

Dalam organisasi apapun, sumber daya manusia adalah yang paling utama dan menentukan kelangsungan hidup sebuah organisasi. Dalam pemerintahan sumber daya manusia sangat berperan dalam menjabarkan makna dan fungsi pemerintahan dan mampu menerjemaahkan serta melaksanakan fungsi-fungsi pemerintahan secara efisien dan efektif. Dari hasil wawancara dengan para informan peneliti memandang bahwa SATPOL PP masih membutuhkan tenaga pegawai yang cukup banyak karena keadaan para penegak perda jumlahnya masih belum memadai sehingga dalam pelaksanaan penertiban masih belum maksimal, karena pihak dinas pun merasa sangan kekurangan 
jumlah anggota untuk melakukan kegiatan penertiban tersebut, karena Bernardin dan Russel dalam (Sutrisno, 2010), mengemukakan bahwa kinerja yang dapat digunakan untuk mengukur kinerja salah satunya yaitu Cost effectiveness Merupakan tingkat sejauh mana penggunaan sumber daya organisasi (manusia, keuangan, teknologi, dan material) dimaksimalkan untuk mencapai keberhasilan.

InterPersonal imfact ( hubungan antar perseorangan) Merupakan tingkat sejauh mana pegawai memelihara harga diri, nama baik, komunikasi, dan kerja sama diantara rekan kerja dan bawahan. Merujuk bahwa komunikasi dalam ranah kinerja juga dapat mempengaruhi kesuksesan dalam hasil kerja itu sendiri. Dalam hal ini sejauh mana komunikasi yang ada turut mendorong keberhasilan dalam hasil kerja yang telah di jalankan. Komunikasi yang tidak baik dapat menjadi biang keladi dari kegagalan dalam perencanaan kinerja tersebut. Oleh sebab itu, upaya untuk menjalankan kinerja harus pula dengan komunikasi yang baik. Pertanyaan pertama kepada informan 1, yaitu : bagaimana komunikasi yang terjalin antar badan pelaksana terutama dengan pihak sekolah?

Dari hasil wawancara dengan informan 1, mengemukakan bahwa koordinasi dan komunikasi dengan pihak SATPOL PP dan pihak sekolah kurang terjalin dengan baik. Komunikasi yang terjalin hanya ketika ada laporan keluhan dari masyarakat mengenai pelajar yang membuat gaduh dan membuat onar. apabila tidak ada laporan pihak dinas yang terkait hanya menjalankan tugasnya masing-masing. Lalu peneliti bertanya kepada informan 2 dengan pertanyaan yang sama. Dari hasil wawancara dengan informan 2, mengemukakan bahwa komunikasi yang terjalin tidak begitu baik, komunikasi dilakukan apabila ada peristiwa tentang pelajar yang meresahkan saja, tidak ada komunikasi yang dilakukan secara rutin dan terus menerus antara pihak sekolah dan pihak SATPOL PP.

Kemudian peneliti melanjutkan pertanyaan yang sama kepada informan 3 Dari hasil wawancara dengan informan 3, mengemukakan bahwa komunikasi yang terjalin hanya ketika ada laporan kejadian pelajar yang membuat kegaduhan saja. Tidak ada komunikasi yang terjalin antara pihak terkait. mengenai pelajar yang membolos di jam pelajaran sekolah yang membuat gaduh dan membuat resah masyarakat setempat. Untuk informan 4 dan informan 5 pertanyaan ini tidak termasuk pertanyaan yang diajukan kepada informan 4 dan informan 5 karena bukan dalam pengetahuan dan bidangnya.

\section{PEMBAHASAN}

Dari jawaban informan tersebut, peneliti dapat menginterpretasikan bahwa komunikasi yang terjalin antara badan penegak hukum dan yang terkait dengan pelajar yang membolos tidak begitu berjalan dengan baik. Ini menjadi PR bagi pemerintah baik penegak ketertiban umum tersebut ataupun para guru di sekolah untuk berusaha menjalin komunikasi dengan baik. Karena komunikasi sangat mempengaruhi keberhasilan kerja dalam menangani para pelajar yang membolos sekolah. 
Dari hasil wawancara peneliti dengan para informan peneliti memandang komunikasi antar badan pelaksana masih dirasa kurang baik karna tidak adanya keseimbangan komunikasi antara para badan pelaksana dengan pihak luar komunikasi yang efektif sangatlah penting karena jika para badan pelaksana dan pihak yang terkait menjalankan komunikasi dengan baik maka sasaran dari keberhasilan dari kinerja akan sangatlah mudah Bernardin dan Russel dalam (Sutrisno, 2010) yang mengemukakan bahwa kinerja yang dapat digunakan untuk mengukur kinerja salah satunya yaitu adalah Interpersonal impact Merupakan tingkat sejauh mana pegawai memelihara harga diri, nama baik, dan kerja sama diantara rekan kerja dan bawahan.

Berdasarkan hasil penelitian dari Beddy (2014) dalam penelitian terdahulu yang berjudul Pelaksanaan Ketertiban Umum (Sudi Kasus Pasar Simpang Padang Duri) di Kecamatan Mandau dengan menggunakan teori Van Meter dan Van Horn hasilnya menunjukan bahwa Dalam pelaksanaan ketertiban yang menjurus kepada sebuah kebijakan yang ada di dalam peraturan daerah, diperlukan sebuah komunikasi yang baik antar pelaksana tugas serta kegiatan kegiatan pelaksanaan, dalam mencapai sebuah tujuan utama peraturan daerah tersebut. Komunikasi merupakan media terpenting dalam organisasi. Dengan adanya komunikasi yang baik dan lancar tentunya akan memudahkan anggota melaksanakan tugasnya, sehingga tujuan dari tugas akan tercapai dengan maksimal. Perlu disadari bahwa kebanyakan kegagalan dalam suatu tujuan adalah kurangnya komunikasi antar anggota.Dalam aktifitas para pedagang kaki lima, dan satpol pp memiliki tanggung jawab penuh untuk menjaga ketertiban umum. Dalam melaksanakan tugasnya tentu para anggota telah mempersiapkan apa apa saja yang akan dilakukan ketika turun ke lapangan.

\section{SIMPULAN}

Berdasarkan hasil penelitian yang telah di deskripsikan peneliti sebelumnya. Mengenai kinerja Satpol PP dalam Upaya Mewujudkan Ketertiban Umum di Kota Sukabumi yang berfokus kepada para pelajar yang membolos sekolah oleh dinas satuan polisi pamong praja ini, peneliti lakukan atau melihat dengan mengacu kepada teori yang dikemukakan oleh Bernardin dan Russel. Karena tidak adanya sangsi hukum yang kuat, Upaya Mewujudkan Ketertiban Umum di Kota Sukabumi yang berfokus kepada para pelajar yang membolos oleh Dinas SATPOL PP Kota Sukabumi masih belum ada keberhasilan atau mendekati tujuan yang diharapkan seperti apa yang diinginkan oleh pembuat kebijakan. Sumber daya atau pegawai di dinas SATPOL PP Kota Sukabumi masih belum cukup para penegak hukum yang ada dalam pelaksanaan kebijakan itu masih membutuhkan tenaga pegawai yang cukup banyak karena keadaan para penegak perda jumlahnya masih belum memadai. Kerja sama belum berjalan dengan baik komunikasi antar badan pelaksana masih dirasa kurang baik karna tidak adanya keseimbangan komunikasi antara para badan pelaksana dengan pihak luar sedangkan 
kerja sama dan komunikasi didalam sebuah kinerja sangatlah penting untuk mencapai sasaran dari keberhasilan kinerja yang akan menjadi evektif.

\section{DAFTAR PUSTAKA}

Sutrisno, E. (2010). Budaya Organisasi. Jakarta: Kencana Prenamedia Group. Peraturan Daerah Nomor 2 Tahun 2004 Tentang Ketertiban Umum Kota Sukabumi. Peraturan Pemerintah (PP) No. 6 Tahun 2010 Tentang Satuan Polisi Pamong Praja.

Vonni, B. (2014). Pelaksanaan Ketertiban Umum (Sudi Kasus Pasar Simpang Padang Duri) di Kecamatan Mandau.

Ibrahim, S.,A. (2015). Hubungan Antara Motivasi Belajar Dengan Perilaku Membolos Pada Siswa Kelas Viii Smp Batik Surakarta.

Gunawan. (2012). Penyelenggaraan Ketentraman Dan Ketertiban Umum Oleh Satpol Pp Dan Penyidik Pegawai Negeri Sipil Di Provinsi Aceh 